\title{
Popular music in Spain: Current lines of research and future challenges
}

\author{
Ruth Piquer \\ Universidad Complutense de Madrid \\ rpiquer@pdi.ucm.es
}

\begin{abstract}
Popular music studies in Spain already have a longstanding history. Their roots are to be found in the academic activity of the 1990s, especially within musicology, anthropology and communication studies. Since then, numerous lines of research have been developed, from the study of local pop rock to the connection of musicology with feminism and queer studies. The intrinsic multidisciplinary nature of popular music studies has facilitated the emergence of many different discussions, in particular the one related to current cultural and social transformations.
\end{abstract}

KEYWORDS: Popular music, Spain, Research, Musicology

\section{Origins}

The development of the academic study of popular music in Spain has its roots in the musicological activity of the 1990s, influenced by contributions from the fields of anthropology, sociology, and communication studies.

The field's emergence is related to the publication of the Diccionario de la Música Española e Iberoamericana("Dictionary of Spanish and Iberoamerican Music"), which began to include references to popular music, as well as to pop and rock music singers, bands, and composers throughout the twentieth century. Researchers such as Silvia Martínez and Héctor Fouce organized a series of meetings devoted to popular music, bringing together scholars from different academic disciplines, including those beyond musicology. The activities of the Department of Anthropology of the CSIC (Consejo Superior de Investigaciones Científicas), led by Josep Martí, were also important regarding these developments, since they paid special attention to music in their research. These early activities contributed to the founding of the Spanish branch of the International Association 
for the Study of Popular Music (IASPM) around the year 1997. The Spanish branch of the IASPM is a working group that has been integrated within the SIbE (Sociedad Ibérica de Etnomusicología) since 2004. The SlbE, founded in 1991 by Enrique Cámara, Josep Martí and Ramón Pelinski, was originally called "Sociedad Ibérica de Etnomusicología" and later "Sociedad de Etnomusicología". This institution gradually came to encompass research on both traditional and popular music, although during its early years its activities (conferences, etc.) were predominantly about traditional and folk music. Such initiatives were in a constant dialogue with the universities, not just within the area of musicology but also incorporating disciplines like communication studies, media studies, anthropology, and sociology. For example, interdisciplinary events like the one celebrated in 2001 in the Complutense University of Madrid, was entitled Mondo Pop: Música, medios e industrias en el siglo XXI ("Mondo Pop: music, media and industries in the $21^{\text {st }}$ century").

The consolidation of musicology as an academic discipline in various Spanish universities was, too, an important factor in the advancement of popular music studies. In the "Music History and Sciences" (Musicology) program offered by the Universidad Complutense, launched in 1997, an optional course on popular music was already planned. Other Spanish universities, like Valladolid, Granada, and Salamanca, also included this subfield in their musicology programs. Later, courses on popular music became mandatory in various curriculums. At the same time, some ethnomusicology courses were launched by scholars like Enrique Cámara and Victoria Eli Rodríguez, promoting an integrated and multidisciplinary perspective in which popular musics including music from TV and other audiovisual media were studied. Although Spanish ethnomusicology had largely been an amalgam of folk music studies, in the vein of the "comparative musicology" of the nineteenth century, it gradually became a vast and versatile cultural discipline, concerned with all sorts of different topics. Trans, for example, the official journal of the SlbE, accurately reflects this process.

The subject area devoted to popular music was called "urban popular music studies" in most universities and research spaces. This was intended to solve the terminological problem that arises in Spanish-speaking countries regarding the definition of "popular music" and its field of study (Jordán 2012; Viñuela 2018). In order to translate the English concept of "popular music" (Tagg 1982) into Spanish, the phrase "urban popular music" was introduced to allow researchers to distinguish between folk, traditional, or orally transmitted music on the one hand often labeled as "popular music" in Spanish - and mass-produced music on the other hand. This "urban popular music" was argued to be dependent on the new recording and broadcasting technologies as well as the modern music industry, although this distinction is still subject to some objections and qualifications.

Following on from the rise of popular music studies in the 1980s and 1990s in Britain and the United States, the discipline was also progressively established in Spain.

\section{Research lines}

Popular music studies in Spain involve research in several areas. Although academics from the English-speaking world focused mainly on the analysis of rock and folk music during the 1980s, they soon showed a growing interest in other 
genres and particularly other musical styles ranging from hip hop to punk. In Spain, since the 1990s, the study of pop and rock gradually became more mainstream with the emergence of some pioneering studies on specific styles and music scenes that are now considered seminal works within the field. Particularly prominent among them were Silvia Martínez's research about the Spanish heavy metal scene (Martínez 1999), and Héctor Fouce's work on pop music and cultural changes in Spain, which gave rise to many subsequent studies focused on the Spanish transition to the Democracy era (Fouce 2002). Within anthropology, Jaume Ayats' (1998) work on music within soccer fan clubs and communities was also groundbreaking.

Current research does not just focus on the development of a particular music style or a specific audience, but also analyzes the relationship between the local and the global, the processes of cultural transference, the spaces where music is played, the audience, the impact of the media and social media, and political and cultural issues. Some ground -breaking examples are Gonzalo Fernández Monte's work on ska music in Spain (2014), Fernán del Val's study of the cultural background of Spanish pop and rock during the Spanish transition era from a sociological perspective (2014), Diego García Peinazo's work on Andalusian rock (2017), Eduardo García Salueña's on progressive rock (2014), Karlos Sánchez Ekiza's about rock in the Basque Country, Sara Arenillas's study of glam rock (2017), Guillermo Delis's of progressive rock (2016), and Fernando Galicia's work on heavy metal (2015).

Spanish scholars have started to discuss other genres like jazz and blues (with seminal works by Iván Iglesias about jazz in Spain $(2010,2017)$, and by Josep Pedro about blues (2018), hip hop (Reyes 2003), electronic music (Leste 2018), and more generally different music scenes associated in turn with different genres and urban spaces. Other examples include Javier Campos's study of Celtic culture and folk in the Galicia area (2015), and Fernando García Barrera's on flamenco and indie music (2014). The study of flamenco is also widespread in Spanish musicology. Some highlights were the studies that contemplated contemporary flamenco music in the light of theoretical questions regarding authenticity, identity, and hybridization with other genres, by authors like Francisco Bethencourt (2011), Juan Zagalaz (2013), and Trinidad Jiménez (2017).

Many of these works have considered issues of cultural transmission, transformation, adaptations, and mixtures, as well as the effect of diasporas and migratory processes influencing local music scenes. Examples of this latter aspect are the work on Cuban musicians in Barcelona by Íñigo Sánchez Fuarros (2008), or the study of salsa music in that same city by Isabel Llano (2015). Also worth noting is Rubén Gómez Muns's doctoral dissertation about the phenomenon of so-called "world music" in Spain (2016).

Regarding musical spaces and the relationship between music and territory, we can also find studies about soundscapes, a topic also covered by historical musicology. Sánchez Fuarros's work on Lisbon (2015) is particularly pioneering in this regard. These lines of research share some ground with various branches of ethnomusicology, as this discipline has also focused on the sonic character of urban landscapes, alongside anthropology and some branches of sociology.

In fact, there is an important line of research dealing with music-related themes within Spanish sociology. Of notable mention is MUSYCA (which stands for "Music, Society, and Artistic Creativity"), a research group founded in 2008 and led by Javier Noya, a professor from the Department of Sociology $\vee$ in the Complutense University of Madrid. Around thirty professors and researchers from different 
academic branches collaborate in this group. They have published a collective volume called MUSYCA, supervised by Javier Noya, Martín Pérez Colman, and Fernán del Val (2010), while also organizing several conferences and activities. Similarly, the UNED (Universidad Nacional de Educación a Distancia) organizes a project, directed by Francisco Cruces and entitled Madrid Cosmópolis: Prácticas emergentes y procesos de metropolización ("Madrid Cosmopolis: Emerging practices and metropolitan processes"), which belongs to the UNED-based group "Cultura Urbana" and is devoted to research on the transformations of the metropolitan area of Madrid, and how those transformations are linked to globalization.

Anthropology, ethnomusicology, sociology, and popular music studies come together in some analyses about the revival processes in folklore and traditional music, as well as studies on the folk music phenomenon, and those related to the issue of identity linked with musical expression, rituals, festivities, music festivals, and revival processes. Regarding these last two aspects, Susana Moreno's work examines the repercussions of festivals and contemporary music-related celebrations within the framework of the corresponding social, political, and economic contexts, paying special attention to phenomena like identity-reaffirming processes, the advance of globalization, the integration of Spain and Portugal within the European Union, the revitalization and re-contextualization of expressive practices, transnational dynamics, and the processes related to the mercantilization, patrimonialization, and touristification of music and culture.

Researchers on scenography, popular music theater, the cuplé, and the copla, have also played a key role in the consolidation of popular music studies, constituting one of the more active lines of research at present. Some prominent figures in this field are Celsa Alonso (2010), Julio Arce (2014), Enrique Encabo (2019), Maruxa Baliñas (2007), Pepa Anastasio (2009), among others, and the field itself is intimately linked to the theoretical frameworks of performance art and the study of body movements and gestures.

Another important line of research focuses on religion and ritual. Josep Martís studies were influential to this development. Recently, an event called Losing my Religion: Espiritualidad, religión y música popular, was held in the city of Santander, in 2017, under the umbrella of the SIbE. Besides religion and ritual, questions related to the interconnection between music and politics, or between music and political protest, are also addressed in the academic literature. There are some studies about Spanish singer-songwriters and their impact on the construction of cultural identities and Spanish politics in general. Among them I would highlight those by Jaume Ayats (2019), Isabelle Marc (2013) from the discipline of philology, and Silvia Martínez (2016). Similarly, the beat era and the influences of international pop music in the 1970s are attracting more attention, because of their significance in the identity formation of young people (Alonso 2010; Otaola 2014).

Broadcast media in Spain have also received attention by some musicologists (Arce 2008a). This includes research on audiovisual musicology and the relationship between music and the moving image. There is a well-established subfield dealing with music and cinema. Research by Jaume Radigales (2006), Josep Lluis i Falcó (2010), Joaquín López (2009), Matilde Olarte (2009), Julio Arce (2008b), Teresa Fraile (2009), and Ramón Sanjuan (2017) has contributed to this. The research is not limited to specific media but encompasses a variety of audiovisual-related research: music videos and audiovisual pieces in the digital era 
(Eduardo Viñuela's 2008), advertising or new audiovisual re-creations through digital technologies (Sánchez 2015; Pedro Buil 2016), as well as remixes, mashups, memes, and other audiovisual creations ( López-Cano 2019; Viñuela 2009; Piquer 2017).

In recent times, feminism and gender studies as academic subjects have reemerged in Spain. Some musicologists started paying attention to these perspectives in the 1990s, with the emergence of the "new musicology". The work of Pilar Ramos entitled Feminismo y música (2003) is pioneering, as well as the studies by Laura Viñuela, focused on popular music (2005). There is also a working group within SIbE devoted to feminist musicology. This line of research has been pursued by scholars who have examined the female presence in particular music scenes or audiences, for example Isabel Ferrer's research about leisure spaces and dance during the Francoist era (2017), and María Teresa López Castilla's work on electronic music has also included aspects of queer musicology (2015).

\section{Future challenges}

Some other lines of research are not as prominent in Spanish academia, but are growing areas nevertheless. Sound studies have opened a fruitful field in Spain, devoted to the multiplicity of sonic experiences. They not only focus on the transmission of sounds, but also on their audience impact, and the conceptualization of music from a perceptual, psychological, and sociological point of view. A research field in the area of music production has also been recently established, being promoted by Marco Antonio Juan de Dios (2016) and Jordi Roquer (2017).

Studies on perception and cognition are still limited in Spanish academia. The psychology of music, which had an important place within systematic musicology originally, is now barely pursued in Spain. Acoustics and the psychology of hearing could be part of this field, although they are linked to a sociological approach, focusing on how musical values and mental representations are perceived. Research studies in this area that highlight contemporary music include those of Ramón Pelinski (2000), and Alicia Pecalba (2008) who addresses the relationship between music and the body. Some other studies about perception and performative acts are currently acquiring some relevance. Rubén López-Cano has published numerous articles in this area from the perspective of semiotics. Recently, the publication of a volume entitled Música y cuerpo. Estudios musicológicos (edited by Teresa Cascudo 2016) is worth noting, as well as the studies by sociologist Amparo Lasén about the body, hearing, and digital technologies in relation to popular music (2017). A related avenue of research addresses individual modes of listening in different contexts (García Quiñones 2008).

The volumes entitled Made in Spain. Studies in Popular Music, edited by Silvia Martínez and Héctor Fouce (2013), and Rock around Spain. Historia, industria y medios de comunicación, edited by Kiko Mora and Eduardo Viñuela (2013), as well as the Journal Trans, portray the plurality that exists within Spanish popular music studies. Looking at the working groups ascribed to the SIbE also offers an interesting picture of the different lines of research currently being pursued.

We should also mention the present place of popular music studies within the universities and higher education institutions. Eduardo Viñuela (2018) points out that the number of Degree courses about popular music has recently multiplied in Spain. Examples of this are the ESMUC, the Universidad Alfonso $X$, the 
Conservatorio Profesional de Navarra, the Escuela de Música Creativa in Madrid, or the Berklee College of Valencia, as well as some courses on popular music within the musicology programs of several public universities, and in other degrees across professional and superior music conservatories (Lasuén 2014).

Within the institutions that have implemented such courses, Bachelor's as well as Master's theses about popular music are being produced, many of them focusing on new genres such as trap and other urban and young musical styles related to social media and other digital environments.

The intrinsic, multidisciplinary nature of popular music studies has offered a transformative vision to Spanish musicology, as has also occurred in other countries and cultural spaces (González, for example, studies the development of this field in Latin America: González 2008). One of the main challenges faced by popular music studies in Spain, besides incorporating a greater presence of the discipline in higher education, is trying to improve the professional prospects of those engaged in it through a "new musicology". Another challenge is to widen the presence of musicologists as music critics within popular media, or integrating them as experts in record labels and other music-related industries. Lastly, popular music experts should focus on digital technologies and multimedia platforms in order to produce new research projects in accordance with the new demands and the new platforms that music in our contemporary societies increasingly requires.

\section{Acknowledgements}

I would like to thank my colleagues Teresa Fraile, Silvia Martínez, Julio Arce, Héctor Fouce and Eduardo Viñuela, as well as the board members of the IASPM Spanish branch, Josep Pedro and Fernán del Val, for the information provided in preparation of this text.

\section{References}

\section{Bibliography}

Alonso, C. -

2010. Símbolos y estereotipos nacionales en la música popular de los años sesenta: Entre la representación y la negociación. In Celsa Alonso González Ed. Creación musical, cultural popular y construcción nacional en la España contemporánea. Madrid: Instituto Complutense de Ciencias Musicales: 205232.

(Ed.). 2010. Creación musical, cultural popular y construcción nacional en la España contemporánea. Madrid: Instituto Complutense de Ciencias Musicales.

Anastasio, P. 2009. Pisa con Garbo: El cuplé como performance. Trans:

Transcultural Music Review = Revista Transcultural de Música, 13. https://www.sibetrans.com/trans/articulo/61/pisa-con-garbo-el-cuple-comoperformance Accessed: 11/11/2019 
Arce, J. -

2008a. Música y radiodifusión: los primeros años (1923-1936). Madrid: Instituto Complutense de Ciencias Musicales.

2008b. La música en el cine mudo: mitos y realidades. In Celsa Alonso González, Carmen Julia Gutiérrez González, Javier Suárez Pajares Eds. Delantera de paraíso: estudios en homenaje a Luis G. Iberni. Madrid: Instituto Complutense de Ciencias Musicales: 559-568.

2014. Del teatro por horas a la zarzuela por metros: la modernidad del teatro lírico filmado en la década de 1920. In María Nagore Ferrer, Víctor S6nchez Sánchez Eds. Allegro cum laude: estudios musicológicos en homenaje a Emilio Casares. Madrid: Instituto Complutense de Ciencias Musicales: 219226.

Arenillas, S. 2017. Discursos, identidades y transgresión en la música popular española (1980-2010): el caso del glam rock y sus variantes. PhD. Universidad de Oviedo, Oviedo.

Ayats, Jaume. 2019. Cançons per construir la història d' un país. In Magí Sunyer Molné Ed. Aureli Capmany. Tarragona, Universitat Rovira i Virgili, Publicacions URV: 11-21.

Bajo González, J. and Fernández Monte, G. 2015. La vida no se detiene. Una crónica del ska en España. Lleida: Milenio.

Baliñas, M. 2007. De mujer objeto a artista independiente. Evolución del mito de la Fomarina. In Manuel-Reyes García Hurtado Ed. El futuro de las humanidades. La Coruña: Universidad de la Coruña: 111-118.

Barrera, F. 2014. Hibridación, globalización y tecnología. flamenco y música indie en Andalucía (1977- 2012). PhD. Universidad de Granada, Granada. https hera.ugr.es/tesisugr/24145518.pdf

Bethencourt Llobet, Francisco. 2011. Rethinking tradition: towards an ethnomusicology of contemporary flamenco guitar. PhD. Newcastle University, Newcastle.

https://www.academia.edu/4942131/Rethinking_tradition_towards_an_ethnom usicology_of_contemporary_flamenco_guitar

Buil, P. 2016. Del videoclip al spot audiovisual: propuesta metodológica de análisis a través de la música mainstream. PhD. Universidad Complutense de Madrid, Madrid. https://eprints.ucm.es/42629/

Campos Calvo-Sotelo, J. 2009. La música popular gallega en los años de la transición política (1975-1982): reificaciones expresivas del paradigma identitario. PhD. Universidad Complutense de Madrid, Madrid.

Casares, E. et alii. 1999. Diccionario de la música española e hispanoamericana. Madrid: Sociedad General de Autores y Editores.

Cascudo, T. Ed. 2016. Música y cuerpo: estudios musicológicos. Logroño: Calanda Music.

Castelo-Branco, S. and Moreno, S. 2018. Music in Portugal and Spain. Experiencing Music, Expressing Culture. New York-Oxford: Oxford University Press.

Delis, G. 2016. El rock progresivo en España como contracultura en los años del tardofranquismo: Canarios y Ciclos. PhD. Universidad Complutense de Madrid, Madrid. https://eprints.ucm.es/42368/1/T38721.pdf

Encabo, E. 2019. Miradas sobre el cuplé en España. Identidades, contextos, artistas y repertorios. Madrid: Instituto Complutense de Ciencias Musicales. 
Fernández Monte, G. 2012. El ska en españa: escena alternativa, musical y trasnacional. PhD. Universidad Complutense de Madrid, Madrid. http://eprints.ucm.es/17426/1/T34076.pdf

Ferrer, I. 2017. Escenificando el género: estrategias corporales en los lugares de ocio de las dйcadas de 1940 y 1950. In Beatriz Martínez del Fresno and Ana María Díaz Olaya Eds. Danza, género y Sociedad. Málaga: Universidad de Málaga: 227-258.

Fouce, $\mathrm{H}$.

2002. "El futuro ya está aquH": música pop y cambio cultural en España 1978-

1985. Madrid, Universidad Complutense de Madrid.

https://eprints.ucm.es/4395/1/T26537.pdf Accessed: 9-11-2019.

2006. El futuro ya está aquí. Madrid: Velecío.

2007. La música pop y rock. Barcelona: Universitat Oberta de Catalunya.

Fraile, T. 2009. La creación musical en el cine español contemporáneo. PhD. Universidad de Salamanca, Salamanca.

Fraile, T. and Radigales, J. 2006. La música en los estudios de comunicación audiovisual: prospecciones y estado de la cuestión. Trípodos, 19, 2006, 98112.

Fraile, T. and Viñuela, Eds. 2012. La música en el lenguaje audiovisual: Aproximaciones multidisciplinares a una comunicación mediática. Sevilla: Arcibel Editores.

Galicia, F. 2015. El Heavy Metal en España, 1978-1985: fases de formación, cristalización y crecimiento. PhD. Universidad Complutense de Madrid, Madrid.

García Peinazo, D. 2017. Rock Andaluz: Significación Musical, Identidades e Ideología en la España del tardofranquismo y la Transición (1969-1982).

Madrid: Sociedad Española de Musicología.

García Salueña, E. -

2014. Nuevas tecnologías, experimentación y procesos de fusión en el rock

progresivo de la España de la transición la zona norte. PhD. Universidad de Oviedo. Oviedo.

2017. Música para la libertad. Nuevas tecnologías, experimentación y procesos de fusión en el rock progresivo de la España de la Transición: el eje noroeste. Norte Sur Discos.

Gómez, R. 2016. World Music en el Mediterráneo (1987-2007): 20 años de escena musical, globalización e interculturalidad. PhD. Universitat Rovira i Virgili, Tarragona.

González, J.P. 2008. Los estudios de música popular y la renovación de la musicología en América Latina: La gallina o el huevo? Trans. Revista Transcultural de Música, 12. https://www.sibetrans.com/trans/articulo/100/losestudios-de-musica-popular-y-la-renovacion-de-la-musicologia-en-america-latina-lagallina-o-el-huevo Accessed: 9-11-2019.

Iglesias, I. -

2010. Improvisando la modernidad: el jazz y la España de Franco, de la Guerra

Civil a la Guerra Fría (1936-1968). PhD. Universidad de Valladolid,

Valladolid. https://dialnet.unirioja.es/servlet/tesis?codigo=192612 
2017. La modernidad elusiva. Madrid, Editorial CSIC Consejo Superior de Investigaciones Científicas.

http://public.ebookcentral.proquest.com/choice/publicfullrecord.aspx?p=5349746.

Jiménez, T. 2017. El lenguaje de Jorge Pardo: metodología y análisis (1975-1997).

PhD. Universidad de Sevilla, Sevilla.

Juan de Dios, M.A. 2016. La figura del productor musical en España: propuestas metodológicas para un análisis musicológico. PhD. Universidad de Oviedo, Oviedo. http:// digibuo.uniovi.es/dspace/handle/10651/38279

Jordán, L. F. and Smith, D. K. 2012. How did popular music come to mean música popular? IASPM Journal, 2: 19-33. doi: 10.5429/2079-3871

Lasén, A. Vidas empapadas en música, subculturas, culturas juveniles y la importancia del estilo. In Juan Albarrán et al. Eds. Doble exposición, Miguel Trillo. Madrid: CA2M Centro de Arte Dos de Mayo: 181-207.

Lasuén, S. 2014. La ausencia de las músicas populares urbanas en las programaciones de los conservatorios españoles: una incoherente tradición normalizada con fecha de caducidad. Cuadernos de ETNOmusicología, 4. http://bit.ly/1GXWZEN. Accessed: 9-11-2019

Leste, E. 2018. Memoria y nostalgia en la industria musical: el caso de la música electronica. PhD. Universidad Complutense de Madrid, Madrid.

Llano Camacho, I. 2015. La salsa en Barcelona. PhD. Universidad Autónoma de Barcelona, Barcelona. https:// ddd.uab.cat/record/165729

Lluis I Falcó, J. 2010. El compositor cinematográfico español: evolución de una profesión (1930-1989). PhD. Universidad de Barcelona, Barcelona.

López, J. 2009. Música y cine en la España del franquismo: el compositor Juan Quintero Muñoz (1903-1980). PhD. Universidad de Granada, Granada.

López, T. 2015. Música electrónica y cultura de club: un estudio postfeminista de la escena española. PhD. Universidad de la Rioja, La Rioja.

López-Cano, R. 2018. Música dispersa. Apropiación, influencias, robos y remix en la era de la escucha digital. Valencia: Musikeon Books.

Marc, I. 2013. Brassens en España: un ejemplo de transferencia cultural. TRANS: revista de traductología, 17, 139-149.

Marc, I. and Green, S. Eds. 2016. The Singer-Songwriter in Europe. Nueva York: Routledge, 2016.

Martínez, S. -

1999. Enganxats al heavy. Cultura, música i trangressió. Lleida: Pagès Editors. 2016. Judges, Guitars, Freedom and the Mainstream. Problematizing the Early

Cantautor in Spain. In Isabelle Marc and Stuart Green Eds. The Singer-

Songwriter in Europe: Paradigms, Politics and Place. London y New York: Routledge: 123-136.

Martínez, S. and Fouce, H. Eds. 2013. Made in Spain. Studies in Popular Music. New York: Routledge.

Mianda, L. and Sanjuán, R. 2017. Eds. Música y medios audiovisuales. Vol II, Análisis, investigación y nuevas propuestas didácticas. Alicante: Letra de palo.

Mora, K. and Viñuela, E., Eds. 2013. Rock around Spain. Historia, industria, y medios de comunicación. Lleida: Universitat de Lleida/ Universidad de Alicante.

Moreno, S. 2015. Música, ecología y desarrollo sostenible en el nordeste transmontano. TRANS-Revista Transcultural de Música. Dossier "Música y relaciones transfronterizas (el caso Trás-os-Montes - Zamora). Enrique Cámara 
e Iván Iglesias Eds., 19. http://www.sibetrans.com/trans/public/docs/06d-trans2015.pdf. Accessed: 11-11-2019.

Noya, J., Del Val, F. and Pérez-Colman, C. (Eds.) 2010. MUSYCA: Música, sociedad y creatividad. Madrid: Biblioteca Nueva.

Olarte, M. 2009. Reflexiones en torno a la música y la imagen desde la musicología Española. Plaza Universitaria Ediciones.

Otaola, P. 2014. Españolismo y señas de identidad en la música pop de los años 60. Dedica. Revista de Educação e Humanidades, 5, 163-177.

Pedro, J. 2019. Apropiación, diálogo e hibridación: escenas de blues en Austin y Madrid. PhD. Universidad Complutense de Madrid, Madrid. https://eprints.ucm.es/51692/

Pelinski, R. 2000. Invitación a la etnomusicología: quince fragmentos y un tango. Madrid: Akal Ediciones, 2000.

Pecalba, A. 2008. La intervención del cuerpo en la interpretación musical: estudio del movimiento no visible. In Música, ciudades, redes: creación musical e interacción social. Electronic resource. Conservatorio Superior de Música de Salamanca.

Piquer, R. 2017. Mash-ups audiovisuales: del vídeo musical al "collage" cinematográfico. In Laura Miranda González and Ramón Sanjuán Eds. Música y medios audiovisuales. Vol II, Análisis, investigación y nuevas propuestas didácticas. Alicante: Letra de palo: 297-310

Quiñones, M. 2008. La música que no se escucha. Aproximaciones a la escucha ambiental. Orquestra del Caos.

Ramos, P. 2003. Feminismo y música: introducción crítica. Madrid: Fundación INVESNES, 2003.

Reyes, F. 2003. Graffiti, breakdance y rap: el hip hop en España. PhD. Universidad Complutense de Madrid, Madrid.

Roquer, J. 2017. Els Sons del paper perforat: aproximacions multidisciplinaries al fenomen de la pianola. PhD. Universidad Autónoma de Barcelona, Barcelona.

Sánchez-Olmos, C. 2015. Musicidad: Música y marcas en el branded content. Sectores, formatos y significado (2009-2013). PhD. Universidad de Alicante, Alicante.

Sánchez, I. 2008. "Esto parece Cuba!": prácticas musicales y cubanía en la diáspora cubana de Barcelona. PhD. Barcelona, Universidad de Barcelona. http://digital.csic.es/handle/10261/10429

Sánchez, I. 2015. De barrio maldito a destino cool. Música y rehabilitación urbana en un barrio lisboeta, InMediaciones de la comunicación, 10: 20-34.

Tagg, P. 1982. Analysing popular music: Theory, method and practice. Popular Music, 2, 37-65.

https://doi.org/10.1017/S0261143000001227 Accessed: 9-11-2019

Val, F del. -

2014. "Rockeros insurgentes, modernos complacientes": juventud, rock y política en España (1975-1985). PhD. Universidad Complutense, Madrid. https://eprints.ucm.es/29411/1/T35941.pdf

2017. Rockeros insurgentes, modernos complacientes: un análisis sociológico del rock en la Transición (1975-1985). Madrid: SGAE. 
Viñuela, E. -

2008. El videoclip en España (1980-1995): gesto audiovisual, discurso y mercado. PhD. Universidad de Oviedo, Oviedo.

2009. El videoclip en España (1980-1995): gesto audiovisual, discurso y mercado. Madrid: Instituto Complutense de Ciencias Musicales.

2018. Popular Music in Higher Education: the Consolidation of Field in

Teaching and Research. Revista internacional de educación musical, 6, (1),

2018. https://doi.org/10.12967/RIEM-2018-6-p003-012 Accessed: 9-11-2019

Viñuela, L. 2005. Musicología feminista y música popular: dos nuevos retos para la musicología. Oviedo: KRK Ediciones.

Zagalaz, J. 2013. El impacto del jazz en la renovación del flamenco: una perspectiva analítica a través de la obra de Paco de Lucía entre 1978 y 1981. In Javier Marín López, Germán Gan Quesada, Elena Torres Clemente, Pilar Ramos López Eds. Musicología global, musicología local. Madrid: SEdeM: 863-880 